\title{
The Tunisian Wetlands Centre: modern uses for the Ottoman Fort of Borj El Loutani (Ghar El Melh)
}

\author{
M. J. Viñals, P. Alonso-Monasterio, M. Alonso-Monasterio \\ \& M. Morant \\ Universitat Politècnica de València, Spain
}

\begin{abstract}
The Fort of Borj El Loutani is part of an architectural complex of three Ottoman fortresses and an old harbour with arsenal dating back to the 17 th century. It is located in Ghar El Melh (60 km from Tunis), on the north-western side of the Gulf of Tunis, on the shore of the lagoon with the same name. The conformation of this coastal land has historically resulted in its use as a strategic site for many civilisations that found in this place a safe refuge - one that is very defensible and away from immediate attacks by sea.

The Fort was built by the Ottomans in 1659 and was used as a military base by an artillery division and as a prison. Over time, the Fort has undergone significant transformations and in 1922 was finally listed as a Tunisian Historic Monument. In 1964, the prison was closed, and, in 1990, the Tunisian government launched a restoration and enhancement project for this site.
\end{abstract}

An interpretation centre was the first modern initiative implemented in 2013. This centre is devoted to Tunisian Wetlands.

This work intends to demonstrate the importance of using these relevant monuments to allocate educational facilities in order to guarantee their maintenance and, thus, to highlight the social dimension of the heritage.

Keywords: defensive architecture, historic buildings, interpretation centre, heritage management.

\section{Introduction and objectives}

Historic buildings have intrinsic value in their own right as the fabric of human achievement in arts, design and construction. They are essential to the spiritual 
and cultural well-being of a nation. Currently, they play an increasingly central role in delivering a wide range of public benefits, including education, economic development, urban and rural regeneration, and cultural development, as well as providing facilities, local identity and sense of place, and attracting visitors, thus encouraging tourism activities.

The value of historic buildings is usually recognised by national laws and also at international level by acceding to various international charters and conventions (e.g., UNESCO World Heritage Convention, Venice Charter).

Moreover, many heritage buildings were built for a use that no longer exists today and, therefore, they are closed, even administratively abandoned, and the passage of time has caused their deterioration.

Heritage elements have close historical links to the places where they are located, and local communities feel strongly about their heritage. There is a wide public acceptance, then, that societies have a duty to conserve their heritage for present and future generations.

The best way to conserve historic buildings, according to many authors and institutions devoted to heritage protection such as English Heritage [1] and Canada's Historic Places [2], is to find viable and compatible new uses that all historical buildings to retain their historic character, conserve significant fabric and keep them in good repair into the future. By doing these things, the historic buildings may continue being an asset to their community.

The adaptation of these historic buildings to new uses must follow certain principles set forth in international charters. For example, the new use will be acceptable only if it has minimal impact on the cultural significance of the site.

This paper presents the implementation of a new educational use for the Fort El Loutani in Ghar el Melh, Tunisia. This project combines heritage conservation and educational goals in the development of an interpretation centre devoted to the wetlands, particularly those of Ghar el Melh, because its environment contributes to the enhancement of its heritage significance.

The research addresses the physical features, history and local ethnographic issues always in relation to the historic building in the hope of providing a quality visitor experience and improving public knowledge and awareness of heritage. The site contains, all blended together, the perfect recipe to make for a unique emotional experience: landscape, history and tradition, biodiversity and nature, and sensory stimulation.

An interpretation centre is an institution for the dissemination of knowledge of natural or cultural heritage. These kinds of centres do not aim to collect, conserve and study objects; rather, they enable visitors to gain a better appreciation of the site's natural and cultural values by providing the necessary information and interpretive tools. These centres work to educate and raise awareness of the heritage sites where they are located [3]. They are considered a low impact use and well suited, then, to be house in historic buildings because they do not require the introduction of large amounts of new services and do not threaten to damage the fabric of buildings with their daily activities.

The interpretation centres are based upon interpretation programmes, which are documents for developing an active use of the heritage and making use of a wide 
range of presentation, animation and communication resources. They are considered planning instruments that employ the greatest number possible of techniques to obtain maximum flexibility and adaptation to the specific circumstances.

\section{Methodology}

This project focuses methodological attention on two fronts: first, on the conceptual framework sustaining the interpretation centre bases; second, on the architectural adaptation of the Fort in order to house the exhibition. Several principles and techniques have been followed.

The Tunisian Wetlands Centre represents the first interpretation centre dedicated to informing the public and enhancing the value of wetlands in the North African region. It serves as a means of communication that brings visitors closer to the natural environment as well as to the Fort Borj El Loutani itself, the magnificent cultural container housing the centre.

The design of interpretation centres has been inspired by the principles of the ICOMOS Charter for the interpretation and presentation of cultural heritage sites and also by the Charter Ethos (International Cultural Tourism Charter Managing Tourism at places of Heritage Significance). The global concept of the centre has been built step by step in the framework of an interpretation programme. It starts with the heritage that will be the axis of the exhibition, then proceeds to the development of the programmatic contents, continuing with the place housing the exhibition and, finally, taking into account the target audiences.

Interpretation, according to Ham $[4,5]$, is an effective management instrument that provokes positive attitudes and behaviours that help to enhance the visitors' appreciation and respect for the site's natural and cultural heritage. The interpretation's aim is not only the mere communication of facts but also the generation of specific meanings in visitors' minds. In fact, through the interpretation we try to promote changes in visitors' cognitive, affective and attitudinal sphere. Thus, interpretation has been widely used by managers of natural and cultural sites as an indirect measure to boost visitors' awareness. Interpretation, then, can be considered a key element of the adaptive reuse process because it helps people to understand how the new life of the building has added a new chapter to its history, providing a sense of continuity from the past to the present.

In the case of The Tunisian Wetlands Centre, the programme has been helped to enhance the values and functions of the natural and cultural resources, involving visitors in the care of the protected area and providing them a quality experience.

Meetings with national stewards, NGOs and workshops with stakeholders have taken place in order to define the conceptual pillars of the interpretation programme. At the same time, several on-site field campaigns were developed to analyse the physical features of the site and to take measures to elaborate the building plans of the Fort and assess its potential to house the centre. A documentary study was carried out to ascertain the significance and value resources of both the Fort and the wetlands. 


\section{The historic building of Borj el Loutani and its environment}

The Fort Borj El Loutani (fig. 1) was built in 1659 and is strategically located in Ghar El Melh (60 km from Tunis), on the north-western side of the Gulf of Tunis, on the shore of the lagoon with the same name and close to the old harbour. The conformation of this coastal land has historically resulted in its use as a strategic site for many civilisations that found in this place a safe refuge for commercial activities, one that is easily defensible and far from immediate attacks by sea. In the Mediterranean Sea, such a strategic location was synonymous with battle ships and battles for control of the site.

This area has a long history linked to the maritime civilisations that date back to the Phoenicians who founded the town of Rusucmona (slightly inland from the present one) and the Utica port. During Carthaginian and Roman times, the area was known as Porto Farina. In those periods, the coastline and lagoon configuration were different; the area existed as a wide gulf (Utique Sea) that evolved into a lagoon due to the infilling of the alluvia of the Medjerda River [6]. In the 13th century, the town started to decline and suffered ups and downs due to Berber and Byzantines pirates until the occupation of the Vandals in the 16th century, becoming a stronghold for Saracen pirates.

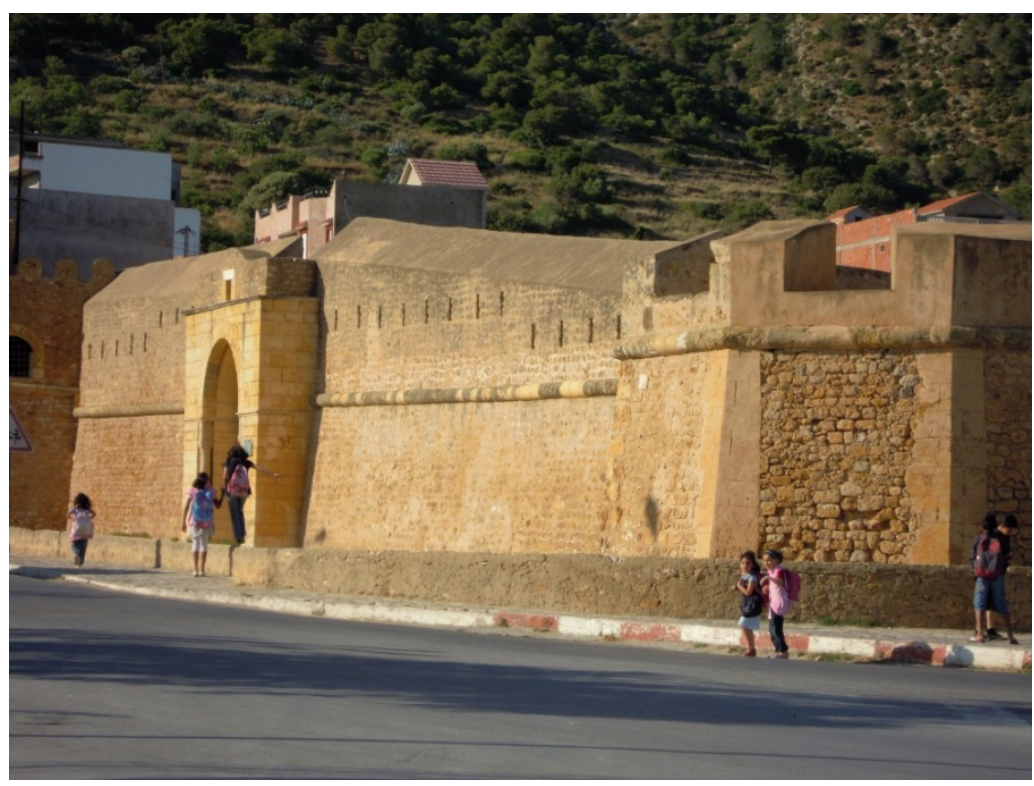

Figure 1: Ottoman Fort of Borj El Loutani (Ghar El Melh, Tunisia).

Later, also in the 16th century, the Spanish Emperor Charles I conquered Ghar El Melh and ordered the construction of a fortress that would be destroyed in the 17th century by the English navy led by Admiral Robert Blake. 
After this episode, Ghar El Melh became once again a base for pirates. Some years later, Ottoman Empire troops reached this coast. During this period, the town had a sort of architectural renaissance, and, in a very short period of time, the area became a very cosmopolitan centre with a good number of Turkish and Levantine colonists who came to establish trading and commercial activities. Nevertheless, the pirates continued harassing the coast, and the Turks decided to build a defensive fortress system to which Fort Borj El Loutani belongs.

Later, new colonists from Malta, France and Sicily increased the cosmopolitan identity of the town with new activities in the 19th century. At the end of the century (1881), Tunisia became a French protectorate, many colonists abandoned the city, and the town was repopulated with new French colonists. In 1956, Tunisia became independent [7].

With respect to the defensive fortress system, it must be noted that the three forts were designed and constructed by Moresque engineers and workers [8], adopting the technique known as hollow masonry [9]. Borj El Loutani has a square floor plant of $3,000 \mathrm{~m}^{2}$ with four crenelated towers placed in the four corners and a central open yard of $900 \mathrm{~m}^{2}$. The perimeter consists of low strong walls on the sides. The entrance is in an arched door located between a tower and a wing that housed the guardhouse. This Borj was used as a military base by an artillery division and also as a prison (probably from the beginning of the Tunis French protectorate till 1964). This Fort, together with the other two fortresses and the arsenal 'El Kishla', were declared a Historic Monument of Tunisia in 1922.

Due to the different uses given to the fort, it has suffered important transformations and strong degradation, mainly because of its use as a civil prison and its abandonment from the end of the sixties till 1990, when the Tunisian government launched a wide enhancement and restoration programme of national monuments and it was decided to house the Tunisian Wetlands Centre there.

This centre is devoted to Tunisian wetlands and especially to the Ghar el Melh Lagoon. This lagoon currently covers a surface area of almost 3,000 hectares and has an average depth of $0.8 \mathrm{~m}$ [10]. In November 2007, it was classified as a Wetland of International Importance (Ramsar Convention) because of its natural values and biological diversity.

The significance of the Fort and surroundings has been established following the English Heritage [1] criteria, which recommend the identification of the evidential, historical, aesthetic and communal values of the site.

Therefore, it should be noted that the Fort has played a key role in the history of the territory. Architecturally, it has been suggested that this Fort, together with the other two, represents the one of the more significant military defence architectural complexes of the Ottoman period in Tunisia. Therefore, the evidential, historical and architectural values of this site can be demonstrated. Moreover, the natural values of the area have also been identified, particularly those related to the wetland. In this sense, it should be stated, as noted above, that the Ghar El Melh Lagoon has the most international environmental recognition as a wetland because of its inclusion on the Ramsar list. Additionally, it has communal value because it is source of prosperity for the local people (fishing, agriculture) and because of its social, spiritual and aesthetic value over time. 


\section{Results: the implementation of the Visitor Centre}

On 25 April 2013, the Tunisian Wetlands Centre was established at the Fort of Borj El Loutani. This centre is a World Wide Fund for Nature (WWF) project, "Wetlands in Tunisia: A Habitat for Man and Nature", supervised by the General Directorate of Forests and the Tunisian National Institute for Heritage representing the Ministry of Culture. The Ramsar Convention, the MedWet Initiative (Mediterranean Regional Initiative of the Ramsar Convention) and the MAVA Foundation were important supporting organisations to this project. The conceptual bases and museographic design was made by Universitat Politècnica de València and the execution were conducted by WWF-Tunis Office.

The project time cycle followed several phases [11]: the initial concept and exhibit design, the exhibit construction and completion; and transfer.

\subsection{Concept and exhibit design}

This part has been devoted to the establishment of the conceptual bases of the interpretation programme that supports the permanent exhibit. The development of these concepts serves the ultimate goal of creating the attitudes, opinions and behaviours, and beliefs of respect that would lead to the long-term preservation of the natural and cultural heritage. Then, certain considerations were taken into account: interpretive objectives, theme and message, presentation resources, spatial location and sequence of the different interpretation stations, (spatial functionality and touring pattern), exhibition features, basic infrastructure, facilities and services and target audiences.

The interpretative objectives of this centre address the protection of the Fort and wetland resources to make the history of this site visible and tangible, to increase heritage appreciation and to raise awareness for locals and tourists, and to enhance visitor experiences by creating learning opportunities. These objectives were turned into themes, as Ham [4] suggested in the development of interpretation programmes.

Therefore, after several sessions and using creative thinking techniques with stewards and key stakeholders, the team developed a concept map of the topic, the themes, and sub-themes, as shown in table 1. Afterwards, the themes were formulated for every sub-topic [12]:

Moreover, in relation to the artistic exhibition design, certain decisions about the 'exhibit style' were made. The team always pursued the consumption of local materials as much as possible, especially those closest to the original construction, avoiding allochthonous materials in order to maintain the heritage features of the Fort and its aesthetic features. The style was also applied to the graphic design. Then, following Moscardo et al. [13], during the designing process the use of colours, typography, the size and length of the titles and the text, the use of logos and finally the graphic materials were taken into account. Furthermore, certain principles of sustainable development have also been taken into consideration, such as the use of recyclable and biodegradable low-impact materials in order to eliminate negative environmental impacts. Another aspect considered was the 
Table 1: Concept tnterpretation map for the Tunisian Wetlands Centre.

\begin{tabular}{|c|c|c|}
\hline \multicolumn{3}{|c|}{ Theme 1: Wetlands Are a Home for Nature } \\
\hline Sub-topic 1 & Typology of wetlands & $\begin{array}{l}\text { Sub-theme1:Tunisian wetlands have } \\
\text { international importance because they } \\
\text { are aquatic ecosystems in a semi-arid } \\
\text { region } \\
\text { Sub-theme } 2 \text { : Being small Tunisia } \\
\text { hosts a large number of wetland types }\end{array}$ \\
\hline Sub-topic 2 & Biodiversity & $\begin{array}{l}\text { Sub-theme } 3 \text { : Wetlands are the most } \\
\text { biodiverse among Tunisian } \\
\text { ecosystems }\end{array}$ \\
\hline $\begin{array}{l}\text { Sub-topic } \\
3\end{array}$ & Birds & $\begin{array}{l}\text { Sub-theme 4: Tunisia is the bridge that } \\
\text { birds use for their flights from south to } \\
\text { north and vice versa }\end{array}$ \\
\hline \multicolumn{3}{|c|}{ Theme 2: Wetlands Are a Home for People } \\
\hline Sub-topic 1 & History & $\begin{array}{l}\text { Sub-theme1: Many civilisations left } \\
\text { their legacy right here }\end{array}$ \\
\hline Sub-topic 2 & Landscape & $\begin{array}{l}\text { Sub-theme 2: The earth is alive, that's } \\
\text { why it continues to change } \\
\text { Sub-theme 3: Wetlands enrich life in } \\
\text { the desert } \\
\text { Sub-theme 4: Ghar el Melh: between } \\
\text { the sea and the land } \\
\text { Sub-them 5: Our lagoon makes this } \\
\text { town special }\end{array}$ \\
\hline Sub-topic 3 & Products & $\begin{array}{l}\text { Sub-theme 6: Ghar el Melh lagoon: the } \\
\text { store of the locals }\end{array}$ \\
\hline Sub-topic 4 & Eco-services & $\begin{array}{l}\text { Sub-theme } 7: \text { Nature offers much more } \\
\text { than you can think of }\end{array}$ \\
\hline \multicolumn{3}{|c|}{ Theme 3: Wetlands Are a Home for Nature and People } \\
\hline Sub-topic 1 & Awareness & $\begin{array}{l}\text { Sub-theme1: What future do you want } \\
\text { for your wetlands? } \\
\text { Sub-theme } 2 \text { : Remember: take care of } \\
\text { wetlands, they are your home }\end{array}$ \\
\hline
\end{tabular}

long-term maintenance of the exhibit elements. Therefore, the team mainly opted for inexpensive manual devices that are easy to maintain and replace.

Supporting the messages of the exhibition could be grouped into:

- Visual exhibits: These refer to the all written materials, panels, maps, etc. The use of illustrations makes it easier for the viewer to understand the message 
and is the most used worldwide [14]. Williams [15] stated that illustrations can be useful to bring objects or places to life, show spatial relationships, demonstrate procedures and provide a context for unfamiliar information. The centre's interpretative stations include illustrations and short texts in order to help visitors contextualise the historical period, the geographical location, a specific type of wetland, etc.

- Audio displays: They rely on the use of sound effects, such as the sound of the sea, the sound of birds or the sound of naval battles, to recreate the Fort's soundscape in the piracy epoch. Audiences are able to listen and relate the sounds to the things they are seeing. Sounds can also help visitors by putting them in a certain mood and tempo and adding a certain depth to the visual experience.

- Three-dimensional displays: They recreate sceneries thanks to the use of original objects or replicas and scenography reconstructions. They enrich the visual information introduced by pictures and text panels, transmitting data and knowledge in an easy and friendly way to visitors, even evoking feelings.

- Interactive exhibits: Interactivity is consubstantial feature of interpretation centres. The present proposal included mechanical tactile exhibits, for example, the traditional irrigation system display, the geomorphological evolution of the Ghar el Melh lagoon, the migratory flyways of birds and the biodiversity issues.

Moreover, some technologically interactive devices supported by digital media were presented, for example, the Ghar El Melh territory virtual flight that works in a similar way to the Google Earth programme. Then, by harnessing the power of technology to educate and entertain, the application makes history come to life and introduces visitors to the exploration of the Tunisian territory.

In relation to audiences, this study identified different types of visitors according to the existent tourist flows and also potential new ones. An important concern is that Ghar El Melh is a known 'sun and beach' Tunisian destination, and many visitors go to the Sidi Ali El Mekki beach in the summer season. Beyond this tourist group, students, families and general public, ecotourists, cultural tourists and adventure tourists are potentials visitors of this centre.

\subsection{Architectural adaptation of the Fort to the modern use}

This part of the study presents the way in which the Fort was architecturally adapted to house the Centre, avoiding any damage to the monument, and carrying out the necessary efforts to culturally harmonise this new use with this magnificent historical building. Nevertheless, the need to house the interpretation centre was likely to drive the design of new elements and the layout of the space. The principle that inspired this work was the preservation and protection of the Fort's integrity and significance. Other considerations were: making the site sustainable and easy to maintain by developing affordable and reasonable actions that kept operational costs low and that also maintained the balance between the investment and expected use, employing long- and short-term property management actions, using durable materials (burn bricks and iron), and local workers and craftsmen, 
engaging the local community early in the project to provide local support and partnerships. Useful guidelines on this topic were again provided by the edited works of English Heritage [16] and other institutions [17].

Moreover, it must be noted that interventions in the significant historic fabric of the Fort have been kept to a minimum. Externally, no additions or changes have been made. The internal plan, forms, aesthetic qualities and decorative schemes have been respected; only the sub-division of the historic volume disrupted the interior, although the partition is absolutely reversible. The walls, windows and roof structure are intact. Some minimum fixtures, fittings and finishes have been necessary to fix on the walls panels and displays. The integrity of the monument, then, has been fully respected. In all actuality, the Fort has demonstrated a great capacity to accommodate this new use.

The interpretation centre is located in the opposite tower to the main entrance. The total available area for the exhibition is $227 \mathrm{~m}^{2}$, divided into 2 main rooms of $100 \mathrm{~m}^{2}$ each ('Tunisian Wetlands Room' and 'Ghar El Melh Room') plus a small space of $27 \mathrm{~m}^{2}$ that hosts the visitor information point (fig. 2). These two large rooms house 14 exhibition stations that present the wetlands in Tunisia, including the related social and economic activities. There is also a 'Hall of Pirates', which traces the history of piracy in the region. A very easy sequential touring pattern has been established to avoid crowding and a minimal number of groups encountered (fig. 3).

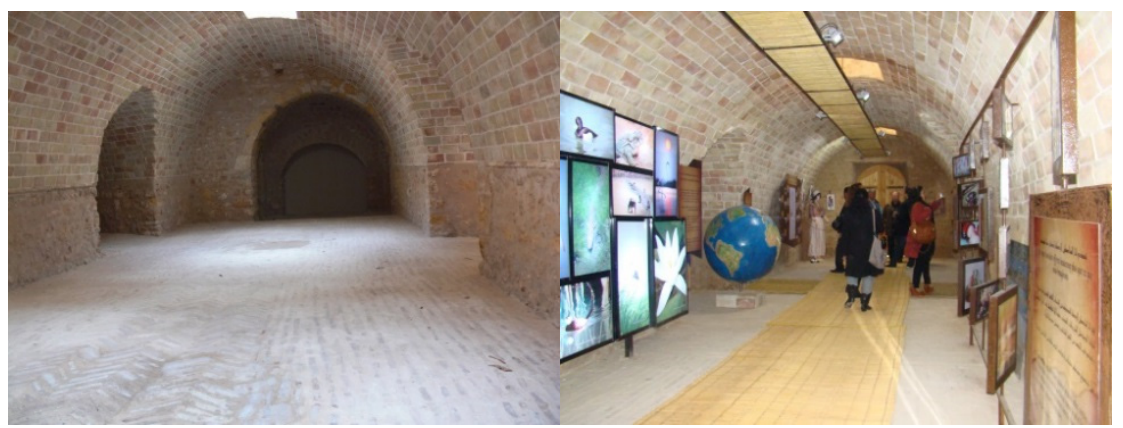

Figure 2: Tunisian Wetlands Room before and after the adaptation to modern use.

\subsection{Transfer and exploitation phase}

In this phase of the project, the managerial issues were the more emergent ones. Therefore, site stewards (international, state and local residents) and stakeholders played a key role. During the development of the project, many meetings with them took place in order to create productive partnerships for site improvement and management because implementation cannot and should not be undertaken without taking into account collaborative partnerships with key organisations. 


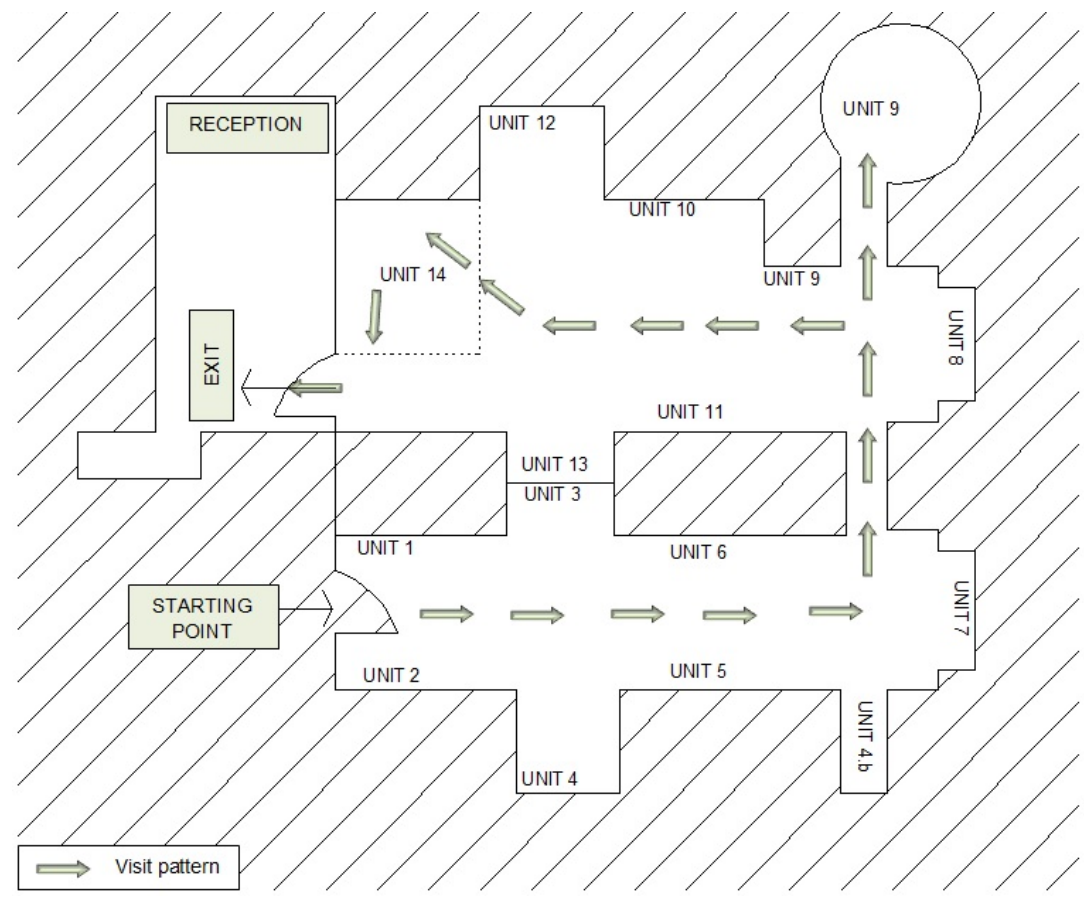

Figure 3: Rooms, interpretation stations and touring pattern of the Tunisian Wetlands Centre.

The results of the project implementation were the transformation of the Fort into a respectful tourist attraction, adding cultural and tourist value to the town of Ghar el Melh. Nevertheless, funds to ensure the long-term maintenance of the centre have not yet been guaranteed. This is an unsolved issue in need of an urgent solution because it also affects the historical building.

Beyond the problems of financial investment, another management-related problem was the need to coordinate the different administrations involved in the management of both assets, that is, the wetland and historic building, in order to optimise available staff, maintenance costs, etc.

\section{Final reflections and concluding remarks}

The programme of research described in this paper highlights the benefits of developing the interpretation centre for Tunisian Wetlands in the Fort of Borj El Loutani. It has demonstrated the success derived from the wise use of an historic building: first, these buildings themselves add value and, second, they usually are wonderful containers for educational and interpretative activities.

From the point of view of the Fort, the interpretation centre was suitable because it is a low impact modern use that threatens neither the integrity of the 
building fabric nor its aesthetic value and, moreover, contributes to the enhancement of its significance and also to its maintenance.

The Tunisian Wetlands Centre benefits by taking advantage of this great heritage asset, which obviously generates additional opportunities to enhance interpretation.

Other findings reveal the benefits related not only to the individual building but also to the wider wetland area and local community.

Currently, it is time to develop best practices to establish an active management policy, and more research efforts should be devoted to providing a clear understanding of the ongoing costs associated with the maintenance of the Fort and the interpretation centre.

\section{References}

[1] Chapple, N., New uses for former places of Worship. Technical report, English Heritage, 20pp., 2012.

[2] Canada's Historic Places: Standards and Guidelines for the Conservation of Historic Places in Canada. Technical report, 288pp., 2010.

[3] Izquierdo, P., Tresserras, J. \& Matamala, J.C., Heritage Interpretation Centres. The Hicira Handbook. Diputació de Barcelona, 125pp., 2005.

[4] Ham, S. Environmental Interpretation: A Practical Guide for People with Big Ideas and Small Budget. Golden, CO: Fulcrum Publishing, 1992.

[5] Ham, S., Meaning Making. The Premise and Promise if Interpretation. Keynote address to Scotland's First National Conference on Interpretation, Edinburg, Scotland, 2002.

[6] Chelbi, F., Paskoff, R., \& Trouset, P., La baie d'Utique et son évolution depuis l'antiquité: une réévaluation géoarchéologique. Antiquités africaines, 31, pp. 7-51, 1995.

[7] Donato, M., Rue des Maltais : la vie de la colonie maltaise de Tunisie. Ed. Gandini, Nice, 2002.

[8] Mouline, N., Ahmad Al-Mansur, sultan de Marruecos y sus ambiciones de reconquistar Al-Andalus. In: Wiegers, G. and Garcia, M. (eds). Los moriscos: expulsión y diáspora. Una perspectiva internacional. Universitat de València, 2013.

[9] Djelloul, N., Les fortifications en Tunisie. Agence de mise en valeur du Patrimoine et de Promotion culturelle, Tunis, 1999.

[10] Azouz, A., Possibilité d'ostréiculture dans le lac de Ghar-El-Melh. Bull. Inst. Natl. Sci. Tech. Océanogr. Pêche, Salammbô, 2(1): 55-8, 1971.

[11] Wideman, R.M., Managing the Project Environment. AEW Services, Vancouver, BC (C) 1990, 2001.

[12] Viñals, M.J., Alonso-Monasterio, M., Halasa, Z., Alonso-Monasterio, P. \& Morant, M., Design of a Centre on Wetlands in Ghar el Melah Lagoon (Tunis). Technical Report, Universitat Politècnica de València, 2010.

[13] Moscardo, G., Ballantyne, R., \& Hughes, K., Designing Interpretive Signs. Principles in Practice, Fulcrum Publishing: Golden, Colorado, Canada, 140pp., 2007. 
[14] Carter, J. (ed) (1997), A sense of place: An interpretative planning handbook. Inverness, Scotland: Tourism and Environment Initiative.

[15] Williams, T.R., Text or Graphic: An Information Processing Perspective on Choosing the More Effective Medium, Journal of Technical Writing and Communication, 23(1), pp. 33-51, 1993.

[16] Catling, Ch. Constructive Conservation. Sustainable growth for historic places. English Heritage, 44pp., 2013.

[17] Heritage Office of NSW Department of Planning \& the Royal Australian Institute of Architects NSW. New Uses for Heritage Places. Guidelines for the adaptation of historic buildings and sites. State of New Wales, 48pp., 2011. 